\title{
Combination Effects of Plant Extracts Rich in Tannins and Saponins as Feed Additives for Mitigating in Vitro Ruminal Methane and Ammonia Formation
}

\author{
Anuraga Jayanegara ${ }^{1} * \mathbb{0}$, Yogianto Yogianto ${ }^{2}$, Elizabeth Wina ${ }^{3}$, Asep Sudarman ${ }^{1}$, \\ Makoto Kondo ${ }^{4}$, Taketo Obitsu ${ }^{5}$ and Michael Kreuzer 6 \\ 1 Department of Animal Nutrition and Feed Technology, Faculty of Animal Science, IPB University, \\ Bogor 16680, Indonesia; a_sudarman@yahoo.com \\ 2 Graduate School of Animal Nutrition and Feed Science, IPB University, Bogor 16680, Indonesia; \\ myogianto@yahoo.com \\ 3 Indonesian Research Center for Animal Production, Ciawi Bogor 16002, Indonesia; winabudi@yahoo.com \\ 4 Department of Bioresources, Mie University, Tsu, Mie 514-8507, Japan; makok@bio.mie-u.ac.jp \\ 5 Graduate School of Integrated Sciences for Life, Hiroshima University, 1-4-4 Kagamiyama, \\ Higashihiroshima 739-8528, Japan; tobitsu@hiroshima-u.ac.jp \\ 6 ETH Zurich, Institute of Agricultural Sciences, Universitätstrasse 2, 8092 Zurich, Switzerland; \\ michael.kreuzer@usys.ethz.ch \\ * Correspondence: anuraga.jayanegara@gmail.com; Tel.: +62-251-862-6213
}

Received: 17 July 2020; Accepted: 27 August 2020; Published: 30 August 2020

Simple Summary: Ruminant livestock contribute to global warming by emitting methane, a major greenhouse gas, as a product of microbial fermentation occurring in the rumen. Apart from its contribution to greenhouse gas emissions, methane emissions represent an energy loss in ruminants. Excessive ruminal ammonia formation, on the other hand, leads to a higher risk of pollution via ammonia, nitrous oxide, and nitrate emissions. Natural plant secondary compounds such as tannins, saponins, and essential oils are among the promising feed additives to mitigate enteric methane and ammonia formation. Though both tannins and saponins, when tested separately, have been reported to be effective, their combinations have rarely been tested. Therefore, in the present study, whether the combination of plant extracts rich in tannins and saponins would act additively or non-additively (associatively) in decreasing methane and ammonia formation in an artificial rumen system was investigated. Indeed, the addition of plant extracts rich in tannins and saponins, either individually or in combination, decreased the methane proportion of total gas in both high-forage and high-concentrate diets. This indicates their effectiveness as anti-methanogenic agents across contrasting diet types. Their effects were generally additive and occasionally synergistic (i.e., more than proportionate), especially in mitigating ruminal ammonia formation and, less clearly, concerning methane emissions.

Abstract: The objective of this experiment was to test the effects of combining plant extracts rich in tannins and saponins at varying proportions on in vitro ruminal methane and ammonia formation. Tannins were extracted from Swietenia mahogani leaves and saponins from Sapindus rarak fruits with various solvents. The extracts obtained with the most efficient solvents (tannins: 75\% water and $25 \%$ methanol; saponins: pure methanol) were then used in vitro. The treatments consisted of two substrate types (high-forage (HF) or high-concentrate (HC) diets) and five extract combinations (tannins: saponins, 1:0, 3:1, 1:1, 1:3, and 0:1) added at $2 \mathrm{mg} / \mathrm{mL}$ in incubation liquid. In vitro incubation was performed in four runs, with each treatment being represented with two replicates per run. The addition of plant extracts rich in tannins and saponins, either individually or in combination, decreased the methane proportion of total gas in both the HF $(p<0.05)$ and HC $(p<0.05)$ diets. The effects of the plant extracts rich in tannins and saponins were generally additive in mitigating 
methane emissions. Favorable associative effects between the extracts were observed in the ammonia concentration, both in the HF $(p<0.001)$ and HC $(p<0.01)$ diets and in the methane proportion of total gas, with a 1:3 mixture of tannins and saponins added to the $\mathrm{HC} \operatorname{diet}(p<0.05)$.

Keywords: plant secondary compounds; methanogenesis; nitrogen; ruminants

\section{Introduction}

The accumulation of various greenhouse gases, such as carbon dioxide, methane, and nitrous oxide, in the atmosphere has been considered to be a primary factor responsible for the current global warming phenomenon. Livestock, particularly ruminants, contribute to anthropogenic greenhouse gas emissions via methane as a product of microbial fermentation occurring in the rumen and, less so, in the hindgut and the manure [1,2]. Such enteric fermentation contributes to approximately $17 \%$ of global methane sources [3], and emission trends are increasing, particularly due to the contribution from developing regions [4]. Methane is formed by archaeal methanogens, predominantly from carbon dioxide and hydrogen as substrates using this mechanism to generate energy under anaerobic conditions [5]. Apart from its contribution to global warming, methane emissions represent an energy loss from livestock on the order of $6-10 \%$ of the gross energy intake of ruminants, especially when forage-based diets are fed [6]. The Intergovernmental Panel on Climate Change (IPCC) [7] assumes a default loss of $6.5 \%$ of gross energy intake for such diets. Reducing methane may therefore improve the efficiency of energy utilization-but only when the mitigation accompanies unchanged energy digestibility. Another type of emission that is of great environmental concern is that of nitrogenous compounds, including ammonia, nitrate, and the greenhouse gas nitrous oxide. These compounds are not emitted directly by the animal; instead, they are formed in the manure from excessive urinary nitrogen. The latter is closely correlated with ammonia formation and absorption from the rumen [8]. Thus, any effective measures to mitigate methane and ammonia formation in the rumen of livestock would be beneficial.

A number of feed additives have been tested for their potential to mitigate methane emissions from ruminants $[9,10]$. Natural plant secondary compounds such as tannins, saponins, and essential oils are among the promising feed additives to mitigate enteric methane emission, and they have been repeatedly investigated [11-15]. For instance, extracted and purified tannins, either condensed (from mimosa and quebracho) or hydrolysable (from chestnut and sumac), added at levels of $0.5-1.0 \mathrm{mg} / \mathrm{mL}$, were shown to substantially decrease the methane per unit of digestible organic matter and methanogen population [16]. Similarly, a methanolic extract of the Saponaria officinalis root (containing saponins) reduced methanogenesis by about $30 \%$ and lowered protozoa and methanogen counts without causing adverse effects on rumen fermentation and in vitro dry matter digestibility [17]. Both tannins [18,19] and saponins $[11,20]$ have also been shown to decelerate ruminal protein degradation and, therefore, prevent the formation of (excessive) ammonia, although their mode of action differs. Tannins bind to proteins at a ruminal $\mathrm{pH}$, thus preventing access by microbes. Saponins hamper the activity of microbes at different steps of protein degradation. Though both tannins and saponins, when tested separately, have been reported to be effective against ruminal methane and ammonia emissions, their efficiency in combination (which could be additive, synergistic, or antagonistic) has rarely been investigated. In a previous study [21], the effects of combining tannin and saponin extracts on in vitro rumen fermentation were tested, but this was performed exclusively with similar proportions between the extracts, and methane formation was not measured. To the best of our knowledge, there has been no study that has attempted to combine plant extracts rich in tannins and saponins in different proportions and to test their effects on rumen methanogenesis.

The objective of the present research was therefore to investigate the effects of combining plant extracts rich in tannins and saponins at varying proportions on in vitro methanogenesis and rumen 
fermentation. The following hypotheses were tested: (1) Extracts from Swietenia mahogani leaves rich in tannins and from Sapindus rarak fruits rich in saponins are effective at decreasing ruminal methane and ammonia formation. (2) When provided in combination, tannins and saponins will act synergistically in this respect owing to the different principles of action. These hypotheses were tested in vitro at varying proportions of tannins and saponins, as well as in two contrasting diet types-a high-forage diet and a high-concentrate diet. The two sources of tannins and saponin were chosen because the two plants are particularly rich in these constituents [22,23]. The extraction of these plant sources at various solvent combinations has not been previously performed.

\section{Materials and Methods}

\subsection{Collection of Plants and Their Enrichment in Tannins and Saponins by Extraction}

Swietenia mahogani leaves and Sapindus rarak fruits were obtained from the area of the Indonesian Research Center for Animal Production, Ciawi Bogor, Indonesia. These plant materials are commonly used as traditional human medicine and for washing "batik," a traditional Indonesian cloth, respectively. Shortly after collection, the plant materials were oven-dried at $50{ }^{\circ} \mathrm{C}$ for $24 \mathrm{~h}$ and subsequently ground to pass through a $0.5-\mathrm{mm}$ sieve. The materials were subjected to various types of solvent extraction to identify the method that resulted in the most concentrated tannin and saponin extracts. The solvents used were water, acetone, and methanol, either alone or in 3:1,1:1, or 1:3 mixtures of either methanol or acetone with water. Ten milliliters of each solvent or solvent combination were inserted into a test tube containing $0.5 \mathrm{~g}$ of the ground plant materials. The tube was then placed in an ultrasonic water bath (Barnstead/Lab Line Aqua Wave 9377, E60H, Germany), and the solvent was allowed to extract tannins or saponins for $20 \mathrm{~min}$ at room temperature. Each sample was then centrifuged (Thermo Scientific IEC Centra CL2 Centrifuge, Fisher Scientific Pte Ltd., Singapore) at $3000 \mathrm{~g}$ and $4{ }^{\circ} \mathrm{C}$ for $10 \mathrm{~min}$. This procedure was repeated twice, and the supernatants were combined and subsequently measured for tannin and saponin concentrations [24,25]. All types of extractions were conducted in three replicates. The solvent types that resulted in the highest tannin and saponin concentrations were subsequently used to prepare the extracts for the in vitro rumen fermentation experiment. For that purpose, the organic solvent was removed by a rotary evaporator (Buchi Rotavapor R-200, Germany), followed by freeze-drying for $24 \mathrm{~h}$ to obtain dry extracts. The dried extracts were then solubilized in distilled water and subjected to in vitro rumen incubation, together with substrates and a rumen-buffer solution.

\subsection{In Vitro Rumen Fermentation}

The two basal diets used as substrates in the in vitro test differed in their forage-to-concentrate proportions. One was a high-forage (HF) diet (forage-to-concentrate ratio: 7:3); the other was a high-concentrate (HC) diet (forage-to-concentrate ratio: 3:7). The forage used was Napier grass (Pennisetum purpureum), which was freshly collected, oven-dried at $50{ }^{\circ} \mathrm{C}$ for $24 \mathrm{~h}$, and then ground to pass through a 1-mm sieve size for further nutrient analysis and in vitro incubation. This screen size was used by the in vitro method employed in the present experiment [26]. Furthermore, a 1-mm screen size has been recommended for in vitro batch culture experiments that assess enteric methane mitigation in ruminants [27]. The concentrate was purchased as a dairy cow concentrate from a local commercial supplier (CV Tani Mulya, Bogor, Indonesia). It was composed of rice bran, cassava pomace, palm kernel cake, copra meal, coffee husk, molasses, $\mathrm{NaCl}$, and a vitamin and mineral mix. The analyzed nutrient composition results of the ingredients are given in Table 1 , and the calculated composition of the complete HF and HC diets is also presented. 
Table 1. Nutrient composition of dried Napier grass, concentrate, and high-forage (HF) and high-concentrate (HC) diets (in $\mathrm{mg} / \mathrm{g}$ dry matter (DM)).

\begin{tabular}{ccccc}
\hline Item & Napier Grass & Concentrate & HF Diet & HC Diet \\
\hline Organic matter & 881 & 942 & 899 & 924 \\
Crude protein & 90 & 184 & 118 & 156 \\
Neutral detergent fiber & 656 & 270 & 540 & 386 \\
Acid detergent fiber & 447 & 117 & 348 & 216 \\
Acid detergent lignin & 94 & 50 & 81 & 63 \\
\hline
\end{tabular}

HF: $700 \mathrm{mg} / \mathrm{g}$ Napier grass and $300 \mathrm{mg} / \mathrm{g}$ concentrate; and HC: $300 \mathrm{mg} / \mathrm{g}$ Napier grass and $700 \mathrm{mg} / \mathrm{g}$ concentrate.

The in vitro rumen fermentation was simulated according to the procedure of Theodorou et al. [26]. One gram of substrate was transferred into a $175-\mathrm{mL}$ serum bottle together with $100 \mathrm{~mL}$ of buffered rumen fluid as the incubation medium. The experimental treatments consisted of $10 \mathrm{mg} / \mathrm{mL}$ of two different substrates (either the HF or HC diets) and five plant extracts rich in tannin and saponin treatments, with the extracts added at $2 \mathrm{mg} / \mathrm{mL}$. In addition, the two basal diet treatments were incubated without extracts, resulting in 12 treatments in total. The five extract treatments comprised $100 \%$ plant extracts rich in tannins $\left(\mathrm{T}_{100}\right)$ or saponins $\left(\mathrm{S}_{100}\right)$ and three combinations of each with 3:1 $\left(\mathrm{T}_{75} \mathrm{~S}_{25}\right), 1: 1\left(\mathrm{~T}_{50} \mathrm{~S}_{50}\right)$, or 1:3 $\left(\mathrm{T}_{25} \mathrm{~S}_{75}\right)$ of $\mathrm{T}$ and $\mathrm{S}$, respectively. These extracts were crude extracts (so may have contained other components), not in the purified forms of tannins or saponins. Following the work of Menke et al. [28], the incubation medium was composed of a bicarbonate buffer solution, a macro-mineral solution, a micro-mineral solution, resazurin, distilled water, a reducing solution, and rumen fluid. The ratio between rumen fluid and the incubation medium was 1:4 (v/v). Rumen fluid, together with rumen solid particles, was collected just before the morning feeding from a rumen-cannulated Holstein Friesian cow cared for following the guidelines of the Federation of Animal Science Societies [29] and housed at the Indonesian Research Center for Animal Production, Ciawi, Bogor. The cow was fed with Napier grass and concentrate $(7: 3 \mathrm{w} / \mathrm{w})$, similar to the substrates used in the in vitro experiment, throughout the whole experimental period in order to minimize the variation among different in vitro incubation runs. Rumen fluid and solid particles were immediately transported into the laboratory (less than $15 \mathrm{~min}$ after collection) and subsequently filtered through four layers of muslin before use. During preparation, the buffered rumen fluid was continuously flushed with $\mathrm{CO}_{2}$ to maintain its anaerobic environment. Serum bottles were sealed with butyl rubber stoppers and aluminum crimp seals shortly before starting the incubation. Incubation was carried out in a water bath maintained at $39^{\circ} \mathrm{C}$ for $48 \mathrm{~h}$. Gas production was vented and recorded at 1, 2, 3, 4, 6, $8,12,16,24,30,36$, and $48 \mathrm{~h}$ after incubation, and the bottles were manually shaken after each gas production reading. The in vitro incubation was performed in four runs, each in a different week. Each treatment per incubation run was represented by two serum bottles. Three bottles per run without any substrate but containing buffered rumen fluid were also incubated to serve as blanks.

\subsection{Chemical Composition, Fermentation Product and Microbial Analyses}

Total phenols and total tannins were measured in the S. mahogani extracts obtained according the procedure used by Makkar [24] by employing the Folin-Ciocalteu method. Polyvinyl polypyrrolidone (PVPP) was used to separate tannin phenols from non-tannin phenols. The absorbance was measured using a spectrophotometer (UV-Vis, U-1800, 5930482, High Technology Corporation, Tokyo, Japan) at a wavelength of $724 \mathrm{~nm}$. Tannic acid was used as the standard for quantification of total extractable phenols and total tannins. The analysis of total saponins in the $S$. rarak extracts was performed according to the work of Hiai and Nakajima [25] and calibrated against a diosgenin standard (Sigma-Aldrich D1634, Sigma Aldrich Chemie GmbH, Steinheim, Germany). Briefly, the sample was added to $0.2 \mathrm{~mL}$ of vanillin, $0.25 \mathrm{~mL}$ of ethanol, and $2.5 \mathrm{~mL}$ of $72 \% \mathrm{H}_{2} \mathrm{SO}_{4}$, and then it was vortexed. Afterwards, it was heated in a water bath (Watson Victor Ltd., Bw6t, Watson Victor Limited, New Zealand) at $60{ }^{\circ} \mathrm{C}$ for 
$10 \mathrm{~min}$. After cooling, the absorbance was determined using the same spectrophotometer as applied for tannins, but at a wavelength of $544 \mathrm{~nm}$.

The substrates were analyzed for dry matter (DM), total ash, crude protein [30], neutral detergent fiber (NDF), acid detergent fiber (ADF), and acid detergent lignin [31]. No $\alpha$-amylase was used for the NDF analysis, and NDF and ADF were expressed without residual ash. Fermentation gas production was recorded by using calibrated glass syringes. Methane concentration was measured in the intervals in the gas release by using the $\mathrm{CO}_{2}$ trapping method with $\mathrm{NaOH}$ according to a study by Fievez et al. [32]. After $48 \mathrm{~h}$ of incubation, the fermentation residue was filtered and dried in an oven at $105{ }^{\circ} \mathrm{C}$ for $24 \mathrm{~h}$. In addition to DM, total ash was determined according to Association of Official Analytical Chemists (AOAC) [30]. Amounts of dry matter and organic matter supply and residue were used to calculate the in vitro dry matter and organic matter degradability (IVDMD and IVOMD, respectively). The ammonia concentration was measured in the incubation liquid obtained after $48 \mathrm{~h}$ by the Conway micro-diffusion technique, as described by Nocek et al. [33]. The volatile fatty acid (VFA) profile was obtained by injecting the incubation liquid into a gas chromatograph (GC 8A, Shimadzu Corp., Kyoto, Japan) following the procedure of Jayanegara et al. [16]. The incubation liquid was fixed with a Hayem solution $\left(2.5 \mathrm{mg} / \mathrm{mL}\right.$ of $\mathrm{HgCl}_{2}, 25 \mathrm{mg} / \mathrm{mL}$ of $\mathrm{Na}_{2} \mathrm{~S}_{4}$, and $5.0 \mathrm{mg} / \mathrm{mL}$ of NaCl$)$ prior to counting the bacteria. To count the protozoa, the incubation liquid was treated with 1:10 diluted formaldehyde (400/100 w/v in water). Bacteria and protozoa populations were counted by using Bürker counting chambers (Blau Brand, Wertheim, Germany) with 0.02 and $0.1 \mathrm{~mm}$ depths, respectively.

\subsection{Statistical Analysis and Calculations}

Data were subjected to an analysis of variance test. The test of the extraction procedures for tannins and saponins was based on a completely randomized design with three replicates per treatment. The in vitro rumen fermentation experiment was based on a randomized complete block design with four replicates (runs) per treatment. Each replicate (run) was represented by the average of two incubation bottles. Different batches of rumen fluid (runs) served as the block. The randomized complete block design was chosen due to insufficient space in the water bath for incubating all the serum bottles at once. When there was a significant effect at $p<0.05$ of any of the treatments, Duncan's multiple range test was conducted for multiple comparisons among treatment means. Bacteria and protozoa counts were transformed into their logarithmic values prior to the analysis of variance. Associative effects between plant extracts rich in tannins and saponins were calculated as the difference between observed values (obtained by the measurements) and expected values (arithmetic means of the values obtained with incubations with tannin or saponin extracts, exclusively). These results are presented as percentage of the expected values [23]. A paired $t$-test was conducted to identify significance between the observed and the expected values. All statistical analyses were performed by using the IBM SPSS statistical software version 20.0. The result tables give the standard errors of the mean (SEM) and $p$-values.

\section{Results and Discussion}

\subsection{Effect of Type of Solvent on the Efficiency of Extraction of Tannins and Saponins}

The extraction of phenols and tannins by either water $(\mathrm{W})$, acetone (A), or methanol (M) alone revealed a low recovery, although there were differences among the three solvents (Figure 1). The order of extraction efficiency for phenols was $\mathrm{M}>\mathrm{W}>\mathrm{A}$, whereas it was $\mathrm{W}>\mathrm{M}>\mathrm{A}$ for tannins. Thus, it seems that solvents with a higher polarity have a better ability to extract phenols and tannins from plant matrices than solvents with a lower polarity. Confirming our findings, Iqbal et al. [34] found that the use of a solvent with a high polarity, such as methanol, increased the efficiency of the extraction of phenols from Artemisia annua leaves. Furthermore, these authors found that the order of different solvents with regard to their ability to extract phenols was $\mathrm{M}>\mathrm{W}>$ ethanol $>\mathrm{A}>$ chloroform $>$ hexane. 


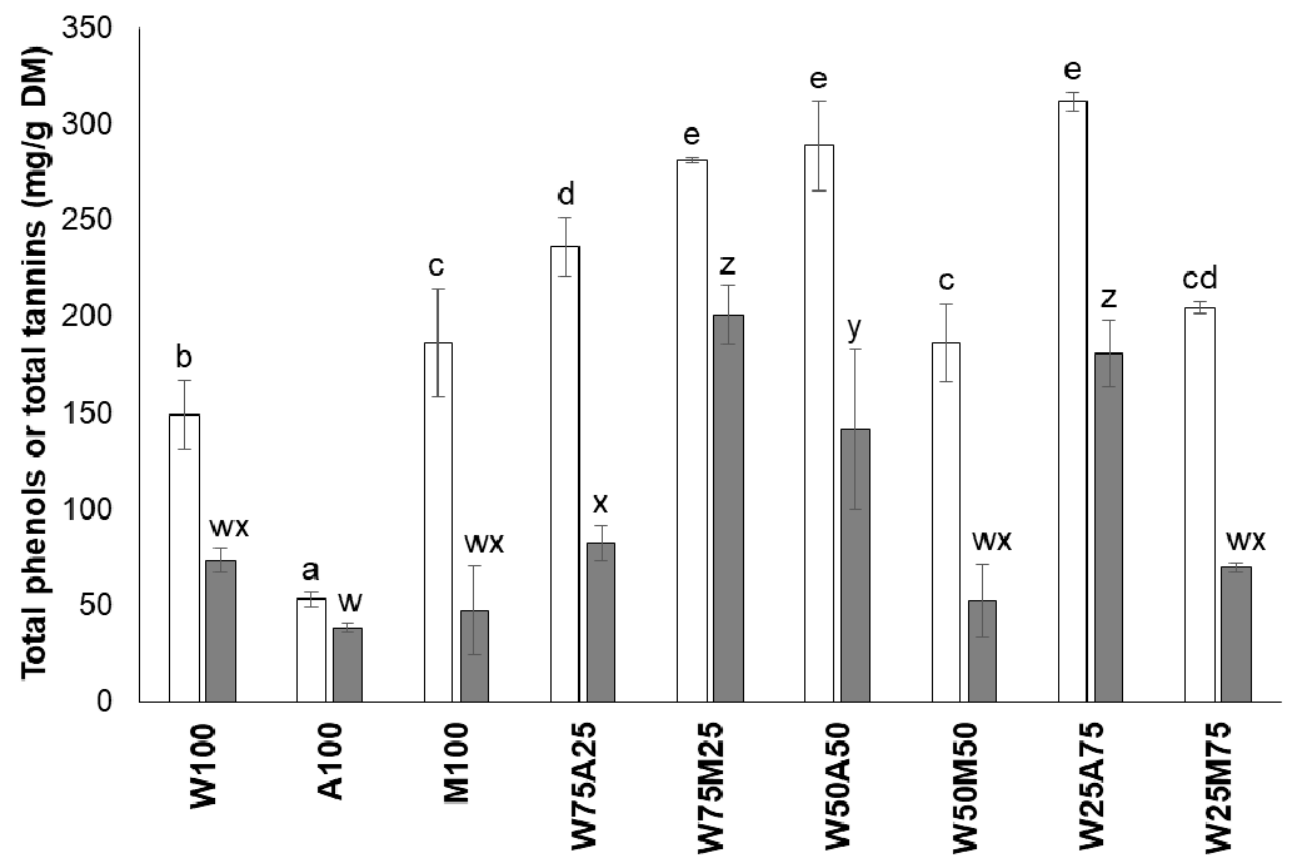

Figure 1. Concentrations of phenols (empty bars) and tannins (grey bars) in the DM of Swietenia mahogani leaf extracts obtained with different solvents (W: water; M: methanol; A: acetone; and numbers describe percentages of the respective solvents used). Bars carrying no common letter within the same parameter are different at $p<0.05$.

Combining $\mathrm{W}$ with either $\mathrm{A}$ or $\mathrm{M}$ improved the extraction efficiency for phenols and tannins $(p<0.05)$, with a few exceptions. The extraction of phenols was particularly efficient (i.e., $>250 \mathrm{mg} / \mathrm{g}$ ) with $\mathrm{W}_{75} \mathrm{M}_{25}, \mathrm{~W}_{50} \mathrm{~A}_{50}$, and $\mathrm{W}_{25} \mathrm{~A}_{75}$, and the extraction with $\mathrm{W}_{75} \mathrm{M}_{25}$ and $\mathrm{W}_{25} \mathrm{~A}_{75}$ resulted in a tannin concentration of $>150 \mathrm{mg} / \mathrm{g}$ DM. An explanation for the higher extraction efficiency of the solvent mixtures compared to the single solvents lies in the chemical structure of the tannins. They contain both hydrophilic (polar) and hydrophobic (nonpolar) groups in their structures, i.e., hydroxyl groups and aromatic phenolic groups, respectively [35]. Makkar [24], for instance, suggested $\mathrm{W}_{30} \mathrm{~A}_{70}$ for extracting tannins from various plant sources. Though this could be seen as a starting point for extracting tannins, efficiency studies for individual tannin sources would better account for the diversity of the chemical structures of tannins occurring across different plants [35]. In the present study, $\mathrm{W}_{75} \mathrm{M}_{25}$ and $\mathrm{W}_{25} \mathrm{~A}_{75}$ were the most effective solvent mixtures. $\mathrm{W}_{75} \mathrm{M}_{25}$ was eventually preferred for extracting tannins from S. mahogani because it required much less organic solvent than the other mixture.

The efficiency of the extraction of saponins from the $S$. rarak fruits was best achieved by using methanol as the exclusive solvent $\left(\mathrm{M}_{100}\right)$. The saponin concentration then was higher $(p<0.05)$ than with any of the other solvents tested (Figure 2). Saponins contain polar glycones and nonpolar aglycones (sapogenin) [15]. Though this chemical diversity is similar to that of the tannins, the extraction efficiency of saponins from $S$. rarak did not increase when using mixtures of solvents. The recommendation by Makkar et al. [36] of using $\mathrm{W}_{50} \mathrm{M}_{50}$ to extract saponins from plant samples was not applicable to S. rarak fruits. This was in agreement with a study conducted by Wina et al. [22], where $\mathrm{M}_{100}$ was also used to extract saponins from $S$. rarak fruits. Therefore, $\mathrm{M}_{100}$ was used as the solvent to extract saponins from the $S$. rarak fruits for the in vitro experiment. 


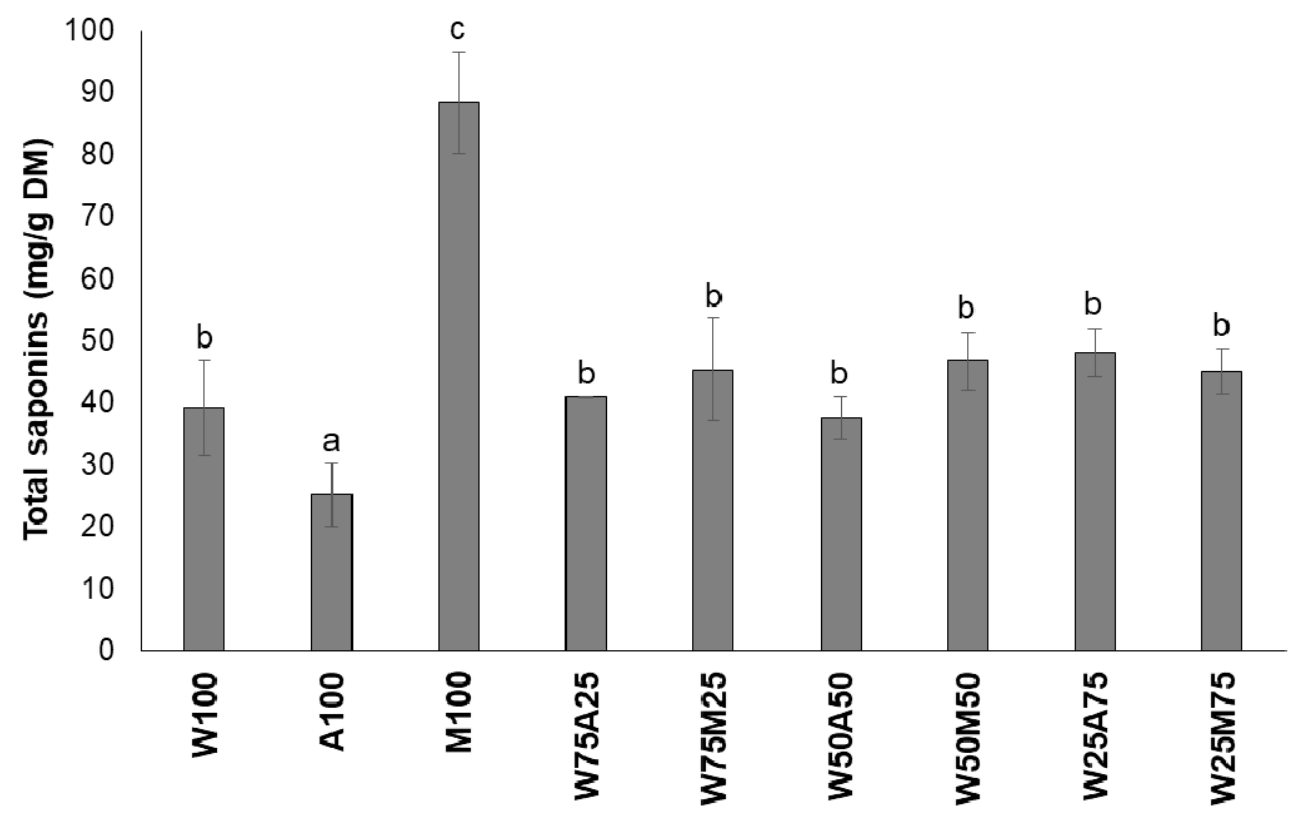

Figure 2. Saponin concentrations in the DM of Sapindus rarak fruit extracts obtained with different solvents. Bars carrying no common letter are different at $p<0.05$.

\subsection{Effects of Basal Diet Type}

Total gas production over 24 and $48 \mathrm{~h}$ was higher when incubating the HC diet compared to the HF diet $(p<0.05$; Table 2), as expected from the lower contents of NDF and ADF (Table 1) and, thus, likely higher contents of non-fiber carbohydrates, especially starch. Consistent with this, Anele et al. [37] observed that high-starch, low-fiber barley grain caused a higher in vitro gas production than low-starch, high-fiber barley grain. Furthermore, the proportion of soluble DM, the fraction of DM insoluble but degradable in the rumen, and the DM disappearance rate were consistently higher in the high-starch compared to the low-starch barley in that study. Consistent with the higher total gas production, IVDMD and IVOMD were higher $(p<0.001)$ with the HC diet than the HF diet (Table 3), whereas bacteria and protozoa counts were not affected by the basal diet type. Bacteria population were considered to be low in this study since they were less than $10^{9}$ cells $/ \mathrm{mL}$. This condition, however, apparently did not lead to a substantial problem, as can be seen from the normal data of rumen fermentation and degradability parameters. Consistent with the higher dietary crude protein content, the HC diet resulted in a higher incubation liquid ammonia concentration $(p<0.001$; Table 3), which was in line with the lower fiber content in a lower methane-to-total gas ratio $(p<0.01$; Table 2$)$. It is well-known that increasing the concentrate proportion in an HC diet will lower its methane emissions [38-40]. In that case, less total fiber and less digestible fiber is available, which leads to smaller amounts of hydrogen for methanogenesis [40].

\subsection{Effects of Plant Extracts Rich in Tannins and Saponins and Their Interaction with Diet Type}

The addition of plant extracts rich in tannins alone $\left(\mathrm{T}_{100}\right)$ did not decrease the total gas production when incubating both the HF and HC diets in comparison to the control (Table 2). The exclusive addition of the plant extracts rich in saponins $\left(\mathrm{S}_{100}\right)$ reduced $(p<0.05)$ the total gas production from the HF diet within $24 \mathrm{~h}$ of incubation $(p<0.05)$, but the effect disappeared within $48 \mathrm{~h}$ of fermentation. No significant effect of $S_{100}$ was observed when added to the HC diet. 
Table 2. In vitro gas production and methane proportion of total fermentation gas, as obtained with fermenting either the HF or the HC diets supplemented with varying proportions of plant extracts rich in tannins (T) and saponins (S).

\begin{tabular}{|c|c|c|c|c|c|}
\hline \multirow{2}{*}{ Diet } & \multirow{2}{*}{ Extract } & \multicolumn{2}{|c|}{ Total Gas (mL/g DM) } & \multicolumn{2}{|c|}{ Methane (mL/L Total Gas) } \\
\hline & & $24 \mathrm{~h}$ & $48 \mathrm{~h}$ & $24 \mathrm{~h}$ & $48 \mathrm{~h}$ \\
\hline \multirow[t]{6}{*}{ HF } & $\mathrm{C}$ & $186^{\mathrm{b}}$ & $233^{a}$ & $277^{d}$ & $286^{\mathrm{d}}$ \\
\hline & $\mathrm{T}_{100}$ & $182^{\mathrm{a}, \mathrm{b}}$ & $242^{b}$ & $221^{a, b}$ & $239^{b, c}$ \\
\hline & $\mathrm{S}_{100}$ & $173^{a}$ & $233^{a}$ & $232^{b, c}$ & $233^{a, b}$ \\
\hline & $\mathrm{T}_{25} \mathrm{~S}_{75}$ & $179^{\mathrm{a}, \mathrm{b}}$ & $245^{b}$ & $218^{a}$ & $226^{a}$ \\
\hline & $\mathrm{T}_{50} \mathrm{~S}_{50}$ & $184^{\mathrm{b}}$ & $247^{\mathrm{b}}$ & $221^{\mathrm{a}, \mathrm{b}}$ & $229^{a, b}$ \\
\hline & $\mathrm{T}_{75} \mathrm{~S}_{25}$ & $187^{\mathrm{b}}$ & $243^{b}$ & $221^{\mathrm{a}, \mathrm{b}}$ & $229^{a, b}$ \\
\hline \multirow[t]{6}{*}{$\mathrm{HC}$} & $\mathrm{C}$ & $236^{d}$ & $275^{c}$ & $238^{c}$ & $247^{c}$ \\
\hline & $\mathrm{T}_{100}$ & $232^{d}$ & $281^{\mathrm{c}, \mathrm{d}}$ & $218^{a}$ & $229^{a, b}$ \\
\hline & $\mathrm{S}_{100}$ & $229^{c, d}$ & $281^{c, d}$ & $227^{a, b, c}$ & $236^{\mathrm{a}, \mathrm{b}}$ \\
\hline & $\mathrm{T}_{25} \mathrm{~S}_{75}$ & $221^{\mathrm{c}}$ & $277^{c, d}$ & $223^{a, b}$ & $230^{a, b}$ \\
\hline & $\mathrm{T}_{50} \mathrm{~S}_{50}$ & $235^{d}$ & $287^{\mathrm{e}}$ & $225^{a, b}$ & $232^{a, b}$ \\
\hline & $\mathrm{T}_{75} \mathrm{~S}_{25}$ & $236^{\mathrm{d}}$ & $285^{\mathrm{d}, \mathrm{e}}$ & $223^{a, b}$ & $232^{a, b}$ \\
\hline $\begin{array}{c}\text { SEM } \\
p \text {-value }\end{array}$ & & 2.8 & 2.4 & 2.1 & 2.0 \\
\hline Diet & & $<0.001$ & $<0.001$ & 0.003 & 0.002 \\
\hline Extract & & 0.001 & $<0.001$ & $<0.001$ & $<0.001$ \\
\hline Diet $\times$ extract & & 0.442 & 0.182 & $<0.001$ & $<0.001$ \\
\hline
\end{tabular}

Means carrying no common superscript within the same column are different at $p<0.05$. HF: $700 \mathrm{mg} / \mathrm{g}$ Napier grass and $300 \mathrm{mg} / \mathrm{g}$ concentrate; HC: $300 \mathrm{mg} / \mathrm{g}$ Napier grass and $700 \mathrm{mg} / \mathrm{g}$ concentrate; and C: unsupplemented control. Indices describe percentages of the respective extracts.

Table 3. In vitro dry matter and organic matter degradability (IVDMD and IVOMD, respectively), ammonia concentration, log bacteria, and log protozoa counts measured after $48 \mathrm{~h}$ of incubation with the HF or HC diets, supplemented with varying proportions of plant extracts rich in $\mathrm{T}$ and $\mathrm{S}$.

\begin{tabular}{|c|c|c|c|c|c|c|}
\hline Diet & Extract & $\begin{array}{l}\text { IVDMD } \\
\text { (mg/g) }\end{array}$ & $\begin{array}{c}\text { IVOMD } \\
\text { (mg/g) }\end{array}$ & $\begin{array}{c}\text { Ammonia } \\
(\mathrm{mmol} / \mathrm{L})\end{array}$ & $\begin{array}{r}\text { Bacteria } \\
(\log / \mathrm{mL})\end{array}$ & $\begin{array}{l}\text { Protozoa } \\
(\log / \mathrm{mL})\end{array}$ \\
\hline \multirow[t]{6}{*}{$\mathrm{HF}$} & C & $629^{d}$ & $704^{f}$ & $24.4^{\mathrm{f}}$ & 8.56 & $6.04^{\mathrm{e}}$ \\
\hline & $\mathrm{T}_{100}$ & $463^{a}$ & $449^{a, b}$ & $20.2^{d}$ & 8.55 & $6.03^{\mathrm{d}, \mathrm{e}}$ \\
\hline & $\mathrm{S}_{100}$ & $520^{b}$ & $505^{c}$ & $20.2^{\mathrm{d}}$ & 8.48 & $5.24^{\mathrm{a}}$ \\
\hline & $\mathrm{T}_{25} \mathrm{~S}_{75}$ & $479^{a}$ & $483^{b, c}$ & $18.7^{\mathrm{c}}$ & 8.53 & $5.68^{b}$ \\
\hline & $\mathrm{T}_{50} \mathrm{~S}_{50}$ & $470^{\mathrm{a}}$ & $444^{\mathrm{a}}$ & $16.6^{\mathrm{a}}$ & 8.47 & $5.62^{b}$ \\
\hline & $\mathrm{T}_{75} \mathrm{~S}_{25}$ & $467^{a}$ & $477^{\mathrm{a}, \mathrm{b}, \mathrm{c}}$ & $16.5^{a}$ & 8.38 & $5.94^{\mathrm{c}, \mathrm{d}}$ \\
\hline \multirow[t]{6}{*}{$\mathrm{HC}$} & $\mathrm{C}$ & $674^{\mathrm{e}}$ & $695^{f}$ & $26.2^{g}$ & 8.23 & $5.98^{\mathrm{c}, \mathrm{d}, \mathrm{e}}$ \\
\hline & $\mathrm{T}_{100}$ & $526^{\mathrm{b}}$ & $548^{d}$ & $19.2^{c}$ & 8.54 & $6.01^{\mathrm{c}, \mathrm{d}, \mathrm{e}}$ \\
\hline & $\mathrm{S}_{100}$ & $604^{c, d}$ & $609^{e}$ & $21.5^{\mathrm{e}}$ & 8.65 & $5.26^{\mathrm{a}}$ \\
\hline & $\mathrm{T}_{25} \mathrm{~S}_{75}$ & $598^{c}$ & $608^{e}$ & $20.7^{d}$ & 8.41 & $5.61^{b}$ \\
\hline & $\mathrm{T}_{50} \mathrm{~S}_{50}$ & $549^{b}$ & $569^{d}$ & $18.8^{c}$ & 8.53 & $5.68^{b}$ \\
\hline & $\mathrm{T}_{75} \mathrm{~S}_{25}$ & $550^{\mathrm{b}}$ & $564^{d}$ & $17.6^{\mathrm{b}}$ & 8.58 & $5.92^{c}$ \\
\hline SEM & & 8.4 & 13.2 & 0.32 & 0.034 & 0.041 \\
\hline \multicolumn{7}{|l|}{$p$-value } \\
\hline Diet & & $<0.001$ & $<0.001$ & $<0.001$ & 0.964 & 0.394 \\
\hline Extract & & $<0.001$ & $<0.001$ & $<0.001$ & 0.790 & $<0.001$ \\
\hline Diet $\times$ extract & & 0.033 & $<0.001$ & $<0.001$ & 0.277 & 0.223 \\
\hline
\end{tabular}

Means carrying no common superscript within the same column are different at $p<0.05$. HF: $700 \mathrm{mg} / \mathrm{g}$ Napier grass and $300 \mathrm{mg} / \mathrm{g}$ concentrate; HC: $300 \mathrm{mg} / \mathrm{g}$ Napier grass and $700 \mathrm{mg} / \mathrm{g}$ concentrate; and C: unsupplemented control. Indices describe percentages of the respective extracts.

For a comparison of the effects of tannins and saponins against methane emission, the proportion of total gas was chosen. A decrease in absolute methane emissions with a concomitant decline in total gas production would likely only reflect the effect of an impaired nutrient degradation and not be based on a real antimethanogenic effect. The addition of plant extracts rich in tannins or saponins 
individually decreased ( $p<0.05$ ) the methane proportion of total gas in both the HF and HC diets (Table 2). This was consistently observed after 24 and $48 \mathrm{~h}$ of incubation. There was an interaction between diet and extract addition $(p<0.001)$ for the methane proportion of the total gas. This was due to the lower magnitude of the methane decrease after the addition of extracts to the HC diet $(8.4 \%$ and $4.6 \%$ after $24 \mathrm{~h}$ incubation with plant extracts rich in tannins and saponins, respectively) compared to the HF diet (20.2\% and 16.2\%, respectively). Different from oils [41], plant secondary compounds are obviously more efficient in forage-based diets. In the present study, the decrease in relative methane formation caused by the addition of the tannin extract was more pronounced $(p<0.001)$ than that found with the saponin extract. However, it was also associated with a decline in the degradability of substrate in the rumen fluid, as was obvious from the lower IVDMD and IVOMD as compared to the control (Table 3). Tannins are able to form complexes with proteins and carbohydrates (both fiber and non-fiber types) through hydrogen or hydrophobic bonds or both, thus making the components less available to microbial degradation and fermentation [42]. Such a condition leads to a lower hydrogen formation, which is relevant because hydrogen is a main substrate for methanogenesis [1]. Tannins may also decrease methane emissions by lowering the methanogen population. In a previous study [16], it was demonstrated that the addition of purified hydrolysable (from chestnut and sumac) and condensed tannins (from mimosa and quebracho) at $1 \mathrm{mg} / \mathrm{mL}$ of the incubation medium reduced the methanogen population by $22.3-36.7 \%$ in comparison to the control. The methanogen count was not measured in the present experiment.

The reduction in relative methane emissions due to the addition of the saponin extract was associated with a lower protozoa population in comparison to the control in both the HC and HF diets $(p<0.05)$ (Table 3). Saponins are known to possess antiprotozoal effects through their interaction with cholesterol in the protozoal cell membrane, which leads to cell lysis; this is true for both triterpenoid and steroid saponins [15]. Since some methanogens live symbiotically with protozoa and protozoa provide hydrogen as a substrate for methane formation [5], any reduction in the protozoa population may decrease the methanogen population and methanogenesis. A lower methanogen population due to the addition of saponins has also been observed in other studies [43,44]. Another plausible mechanism by which saponins decrease methane emissions is by lowering the hydrogen supply from bacteria and fungi [45]. The addition of the saponin extract simultaneously decreased the proportion of acetate and increased the proportion of propionate compared to the control $(p<0.05 ;$ Table 4$)$. Such shifts in VFA profiles lead to further reductions in methane emissions since, stoichiometrically, the formation of acetate from monosaccharide fermentation produces hydrogen, whereas the formation of propionate requires hydrogen [1].

The addition of exclusively plant extracts rich in tannins or saponins reduced the ammonia concentration in the incubation medium of both the HF and HC diets ( $p<0.05$; Table 3$)$. The decline in the ammonia concentration was more pronounced in the high-concentrate diet than in the high-forage diet (interaction, $p<0.001$ ), being $26.7 \%$ and $17.9 \%$ with plant extracts rich in tannins and saponins, respectively, compared to $17.2 \%$ with the HF diet and any of the extracts. Plant extracts rich in tannins and saponins were thus able to effectively decrease the ruminal ammonia concentration. The greater potential, especially for tannins, for reducing the ammonia concentration when incubating the $\mathrm{HC}$ vs. the HF diets was likely due to the greater dietary crude protein content, as a lower proportion was utilized by the microbes to form their own protein. Furthermore, more protein was available to be rendered inaccessible and degraded to ammonia by the microbes due to binding by the tannins.

The lower IVDMD and IVOMD values found in both diets in response to the addition of plant extracts rich in tannins and saponins may be associated with decreasing counts of protozoa, and adverse effects of tannins and saponins are known [14,15]. A decline was not seen for the bacterial count. One reason for this could be the peptidoglycan layer, which is present in the cell wall of bacteria but not of protozoa and which could make bacteria more resistant to plant secondary compounds. 
Table 4. Volatile fatty acid (VFA) profiles measured after $48 \mathrm{~h}$ of incubation of the HF or HC diets supplemented with varying proportions of plant extracts rich in $\mathrm{T}$ and $\mathrm{S}$.

\begin{tabular}{|c|c|c|c|c|c|c|c|c|c|}
\hline Diet & Extract & $\begin{array}{l}\text { Total VFA } \\
(\mathrm{mmol} / \mathrm{L})\end{array}$ & $\begin{array}{l}\mathrm{C}_{2} \\
(\%)\end{array}$ & $\begin{array}{l}\mathrm{C}_{3} \\
(\%)\end{array}$ & $\begin{array}{l}\mathrm{C}_{4} \\
(\%)\end{array}$ & $\begin{array}{c}\text { iso }_{4} \\
(\%)\end{array}$ & $\begin{array}{l}\mathrm{C}_{5} \\
(\%)\end{array}$ & $\begin{array}{c}\text { iso } \mathrm{C}_{5} \\
(\%)\end{array}$ & $\mathrm{C}_{2} / \mathrm{C}_{3}$ \\
\hline \multirow[t]{6}{*}{$\mathrm{HF}$} & $\mathrm{C}$ & $84.6^{b, c}$ & $54.9^{b, c}$ & $26.2^{a}$ & $9.80^{\mathrm{d}, \mathrm{e}}$ & $4.40^{c}$ & $1.54^{\mathrm{d}, \mathrm{e}}$ & $3.20^{c}$ & $2.10^{\mathrm{d}, \mathrm{e}}$ \\
\hline & $\mathrm{T}_{100}$ & $80.8^{\mathrm{a}, \mathrm{b}}$ & $55.7^{b, c}$ & $27.9^{a, b}$ & $8.82^{a, b, c}$ & $4.15^{b, c}$ & $1.30^{b, c, d, e}$ & $2.12^{\mathrm{a}}$ & $2.00^{c, d, e}$ \\
\hline & $\mathrm{S}_{100}$ & $77.7^{\mathrm{a}, \mathrm{b}}$ & $52.6^{\mathrm{a}, \mathrm{b}}$ & $32.5^{\mathrm{e}}$ & $8.15^{\mathrm{a}}$ & $3.36^{\mathrm{a}}$ & $1.06^{a, b, c}$ & $2.05^{\mathrm{a}}$ & $1.63^{\mathrm{a}}$ \\
\hline & $\mathrm{T}_{25} \mathrm{~S}_{75}$ & $83.4^{\mathrm{a}, \mathrm{b}, \mathrm{c}}$ & $55.2^{b, c}$ & $30.3^{\mathrm{c}, \mathrm{d}}$ & $8.10^{a}$ & $3.49^{\mathrm{a}, \mathrm{b}}$ & $0.96^{\mathrm{a}, \mathrm{b}}$ & $1.92^{\mathrm{a}}$ & $1.84^{\mathrm{a}, \mathrm{b}, \mathrm{c}}$ \\
\hline & $\mathrm{T}_{50} \mathrm{~S}_{50}$ & $91.4^{b, c}$ & $56.8^{c}$ & $28.9^{b, c}$ & $8.08^{a}$ & $3.50^{\mathrm{a}, \mathrm{b}}$ & $0.85^{\mathrm{a}}$ & $1.85^{\mathrm{a}}$ & $1.97^{\mathrm{c}, \mathrm{d}, \mathrm{e}}$ \\
\hline & $\mathrm{T}_{75} \mathrm{~S}_{25}$ & $63.1^{\mathrm{a}}$ & $56.0^{\mathrm{c}}$ & $29.8^{b, c, d}$ & $8.32^{a, b}$ & $3.76^{a, b, c}$ & $0.96^{\mathrm{a}, \mathrm{b}}$ & $2.08^{a}$ & $1.90^{c, d}$ \\
\hline \multirow[t]{6}{*}{$\mathrm{HC}$} & $\mathrm{C}$ & $79.9^{a, b}$ & $55.4^{b, c}$ & $26.0^{a}$ & $10.3^{\mathrm{e}}$ & $3.83^{a, b, c}$ & $1.45^{\mathrm{c}, \mathrm{d}, \mathrm{e}}$ & $3.00^{b, c}$ & $2.14^{\mathrm{e}}$ \\
\hline & $\mathrm{T}_{100}$ & $76.0^{a, b}$ & $55.4^{b, c}$ & $27.8^{\mathrm{a}, \mathrm{b}}$ & $9.26^{c, d}$ & $3.76^{a, b, c}$ & $1.14^{\mathrm{a}, \mathrm{b}, \mathrm{c}, \mathrm{d}}$ & $2.38^{a, b}$ & $2.00^{c, d, e}$ \\
\hline & $\mathrm{S}_{100}$ & $102^{c}$ & $51.4^{\mathrm{a}}$ & $31.4^{\mathrm{d}, \mathrm{e}}$ & $8.52^{a, b, c}$ & $3.53^{a, b}$ & $1.69^{\mathrm{e}}$ & $2.33^{a}$ & $1.66^{\mathrm{a}, \mathrm{b}}$ \\
\hline & $\mathrm{T}_{25} \mathrm{~S}_{75}$ & $84.8^{b, c}$ & $53.8^{\mathrm{a}, \mathrm{b}, \mathrm{c}}$ & $29.7^{b, c, d}$ & $9.08^{b, c, d}$ & $3.67^{a, b}$ & $1.28^{b, c, d, e}$ & $2.46^{\mathrm{a}, \mathrm{b}}$ & $1.82^{\mathrm{a}, \mathrm{b}, \mathrm{c}}$ \\
\hline & $\mathrm{T}_{50} \mathrm{~S}_{50}$ & $90.9^{b, c}$ & $52.6^{\mathrm{a}, \mathrm{b}}$ & $29.2^{b, c}$ & $9.31^{\mathrm{c}, \mathrm{d}}$ & $3.89^{a, b, c}$ & $1.32^{b, c, d, e}$ & $2.51^{\mathrm{a}, \mathrm{b}}$ & $1.88^{b, c, d}$ \\
\hline & $\mathrm{T}_{75} \mathrm{~S}_{25}$ & $86.7^{b, c}$ & $53.6^{a, b, c}$ & $28.8^{b, c}$ & $9.17^{c, d}$ & $3.89^{a, b, c}$ & $1.17^{a, b, c, d}$ & $2.40^{a, b}$ & $1.78^{a, b, c}$ \\
\hline $\begin{array}{c}\text { SEM } \\
p \text {-value }\end{array}$ & & 2.41 & 0.380 & 0.402 & 0.139 & 0.075 & 0.048 & 0.076 & 0.036 \\
\hline Diet & & 0.133 & 0.016 & 0.334 & $<0.001$ & 0.999 & 0.003 & 0.013 & 0.429 \\
\hline Extract & & 0.356 & 0.022 & $<0.001$ & $<0.001$ & 0.029 & 0.007 & $<0.001$ & $<0.001$ \\
\hline Diet $\times$ extract & & 0.046 & 0.258 & 0.917 & 0.491 & 0.185 & 0.031 & 0.385 & 0.724 \\
\hline
\end{tabular}

Means carrying no common superscript within the same column are different at $p<0.05$. HF: 700 mg/g Napier grass and $300 \mathrm{mg} / \mathrm{g}$ concentrate; HC: $300 \mathrm{mg} / \mathrm{g}$ Napier grass and $700 \mathrm{mg} / \mathrm{g}$ concentrate; C: unsupplemented control; and VFA: volatile fatty acids. Indices describe percentages of the respective extracts.

It has to be mentioned that fermentation products and microbial counts were analyzed only after $48 \mathrm{~h}$ of incubation-not after $24 \mathrm{~h}$, as for gas production. However, even though gas production values were not twice as high after $48 \mathrm{~h}$ as those after $24 \mathrm{~h}$, the treatment differences were similar, suggesting that these effects were likely similar after $48 \mathrm{~h}$ in all other traits as well.

\subsection{Effects of Combining Plant Extracts Rich in Tannins and Saponins}

Combinations of plant extracts rich in tannins and saponins generally acted additively on the total gas production, methane concentration, IVDMD, IVOMD, and total VFA. Only few associative effects between the extracts, i.e., effects where combinations deviated from the average of those obtained with the extract alone, were observed (Table 5). Concerning methane proportion of total gas, the $\mathrm{T}_{25} \mathrm{~S}_{75}$ combination was more effective $(p<0.05)$ than expected from incubating plant extracts rich in tannins or saponins alone. With regard to ammonia concentration, there were much clearer associative effects of the combined addition of plant extracts rich in tannins and saponins-with both the HF and HC diets. The $T_{25} S_{75}, T_{50} S_{50}$, and $T_{75} S_{25}$ extracts resulted in a lower ammonia concentration $(p<0.05)$ than that expected from the average of plant extracts rich in tannins and saponins incubated alone. One exception was the $\mathrm{T}_{25} \mathrm{~S}_{75}$ extract added to the $\mathrm{HC}$ diet. Tannins and saponins have different mechanisms by which they decrease ruminal ammonia formation, and they therefore seem to act more intensively when given in combination. By binding protein molecules in feed, tannins slow down the rate and extent of protein degradation and amino acid deamination to ammonia [23]. By contrast, saponins lower ammonia concentration, especially via direct antimicrobial effects; these include antiprotozoal effects [15]. Protozoa intensively predate bacteria, thus reducing the efficiency of total microbial protein synthesis and, thereby, the removal of ammonia. On the other hand, saponins inhibit proteolytic rumen bacteria such as Streptococcus bovis, Butyrivibrio fibrisolvens, and Prevotella bryantii [46,47]. 
Table 5. Associative effects ${ }^{\dagger}$ of the combinations between plant extracts rich in $\mathrm{T}$ and $\mathrm{S}$ added to the HF or HC diets.

\begin{tabular}{|c|c|c|c|c|c|c|c|c|c|}
\hline Diet & Extract & $\begin{array}{c}\text { Gas } 24 \text { h } \\
\text { (mL/g DM) }\end{array}$ & $\begin{array}{c}\text { Gas } 48 \mathrm{~h} \\
(\mathrm{~mL} / \mathrm{g} \mathrm{DM})\end{array}$ & $\begin{array}{c}\mathrm{CH}_{4} 24 \mathrm{~h} \\
(\mathrm{~mL} / \mathrm{L} \text { gas) }\end{array}$ & $\begin{array}{c}\mathrm{CH}_{4} 48 \mathrm{~h} \\
(\mathrm{~mL} / \mathrm{L} \text { gas) }\end{array}$ & $\begin{array}{c}\text { IVDMD } \\
48 \mathrm{~h} \\
(\mathrm{mg} / \mathrm{g})\end{array}$ & $\begin{array}{c}\text { IVOMD } \\
48 \mathrm{~h} \\
(\mathrm{mg} / \mathrm{g})\end{array}$ & $\begin{array}{c}\text { Total VFA } \\
48 \mathrm{~h} \\
(\mathrm{mmol} / \mathrm{L})\end{array}$ & $\begin{array}{c}\text { Ammonia } \\
48 \mathrm{~h}(\mathrm{mmol} / \mathrm{L})\end{array}$ \\
\hline \multirow[t]{3}{*}{$\mathrm{HF}$} & $\mathrm{T}_{25} \mathrm{~S}_{75}$ & 4.4 & 4.1 & $-4.9 * *$ & $-3.2 *$ & -5.6 & -1.7 & 7.8 & $-8.2^{* * *}$ \\
\hline & $\mathrm{T}_{50} \mathrm{~S}_{50}$ & 3.9 & 3.0 & -2.0 & -1.9 & -4.6 & -6.9 & $-21.1^{*}$ & $-16.3^{* * *}$ \\
\hline & $\mathrm{T}_{75} \mathrm{~S}_{25}$ & $3.7 *$ & 0.9 & 1.3 & 0.1 & -2.2 & 3.0 & 1.3 & $-19.6^{* * *}$ \\
\hline \multirow[t]{3}{*}{$\mathrm{HC}$} & $\mathrm{T}_{25} \mathrm{~S}_{75}$ & -4.6 & -2.1 & -0.6 & -1.8 & 2.2 & 2.3 & 8.1 & -1.5 \\
\hline & $\mathrm{T}_{50} \mathrm{~S}_{50}$ & 2.4 & $3.0 * *$ & 1.0 & -0.1 & -3.0 & -1.8 & 12.2 & $-6.8^{* *}$ \\
\hline & $\mathrm{T}_{75} \mathrm{~S}_{25}$ & 2.1 & 2.0 & 1.3 & 0.4 & 0.9 & 0.2 & 11.7 & $-13.5^{* *}$ \\
\hline
\end{tabular}

${ }^{*} p<0.05 ;{ }^{* *} p<0.01 ;{ }^{* * *} p<0.001 ;{ }^{\dagger}$ Difference between observed values (obtained by measurements) and expected values (arithmetic means of the values obtained with incubations with exclusively plant extracts rich in tannins or saponins) in percent of the expected values; HF: $700 \mathrm{mg} / \mathrm{g}$ Napier grass and $300 \mathrm{mg} / \mathrm{g}$ concentrate; HC: $300 \mathrm{mg} / \mathrm{g}$ Napier grass and $700 \mathrm{mg} / \mathrm{g}$ concentrate; $\mathrm{CH}_{4}$ : methane; DM: dry matter; IVDMD: in vitro dry matter degradability; IVOMD: in vitro organic matter degradability; and VFA: volatile fatty acids. Indices describe percentages of the respective extracts.

\section{Conclusions}

Tannin and saponin additions in the form of extracts of Swietenia mahogani and Sapindus rarak were shown to be effective in the mitigation of ruminal methane and ammonia formation in every basal diet type-though they were more effective in the forage-based diet in the case of methane and in the concentrate-based diet in the case of ammonia. A particularly interesting finding was that the presence of the frequent additivity of the effects of tannins and saponins which, when combined, made them predictable from the effects of the pure extracts. However, both additives obviously interacted synergistically in protecting part of the protein from ruminal degradation, as could be seen from the particularly low rumen ammonia concentration with combinations. Combinations would therefore need lower amounts of such costly extracts in abating $\mathrm{N}$ emissions through concomitantly losing less $\mathrm{N}$ as volatile urine. A drawback is that both extracts impeded feed degradability. How far this translates into lower performance and affects the extent to which methane and $\mathrm{N}$ emissions can be recovered with combinations of the two plant secondary compounds in vivo remains to be investigated.

Author Contributions: Conceptualization, A.J.; methodology, A.J., Y.Y., E.W., and A.S.; validation, Y.Y.; formal analysis, A.J. and Y.Y.; investigation, Y.Y.; data curation, M.K. (Makoto Kondo), T.O., and M.K. (Michael Kreuzer); writing-original draft preparation, A.J. and Y.Y.; writing-review and editing, M.K. (Makoto Kondo), T.O., and M.K. (Michael Kreuzer); supervision, E.W. and A.S.; funding acquisition, A.J. All authors have read and agreed to the published version of the manuscript.

Funding: This research was financially supported by the Ministry of Research and Technology, Republic of Indonesia, through a 2020 World Class Research Grant (contract number: 121/SP2H/AMD/LT/DRPM/2020).

Acknowledgments: The authors are grateful to Nanang Krisnawan, Antonius Chaniago, and Pristian Yuliana for their technical help during the experimental period.

Conflicts of Interest: The authors declare no conflict of interest.

\section{References}

1. Moss, A.R.; Jouany, J.P.; Newbold, J. Methane production by ruminants: Its contribution to global warming. Ann. Zootech. 2000, 49, 231-253. [CrossRef]

2. Shibata, M.; Terada, F. Factors affecting methane production and mitigation in ruminants. Anim. Sci. J. 2010, 81, 2-10. [CrossRef]

3. Knapp, J.R.; Laur, G.L.; Vadas, P.A.; Weiss, W.P.; Tricarico, J.M. Enteric methane in dairy cattle production: Quantifying the opportunities and impact of reducing emissions. J. Dairy Sci. 2014, 97, 3231-3261. [CrossRef]

4. Dangal, S.R.S.; Tian, H.; Zhang, B.; Pan, S.; Lu, C.; Yang, J. Methane emission from global livestock sector during 1890-2014: Magnitude, trends and spatiotemporal patterns. Glob. Chang. Biol. 2017, 23, 4147-4161. [CrossRef] [PubMed]

5. Morgavi, D.P.; Forano, E.; Martin, C.; Newbold, C.J. Microbial ecosystem and methanogenesis in ruminants. Animal 2010, 4, 1024-1036. [CrossRef] [PubMed] 
6. Cottle, D.J.; Nolan, J.V.; Wiedemann, S.G. Ruminant enteric methane mitigation: A review. Anim. Prod. Sci. 2011, 51, 491-514. [CrossRef]

7. IPCC. Guidelines for National Greenhouse Inventories: Agriculture, forestry and other land use. In Emissions from Livestock and Manure Management; Institute of Global Environmental Strategies: Kanagawa, Japan, 2006; Volume 4, pp. 10.1-10.87.

8. Dijkstra, J.; Oenema, O.; Bannink, A. Dietary strategies to reducing N excretion from cattle: Implications for methane emissions. Curr. Opin. Environ. Sustain. 2011, 3, 414-422. [CrossRef]

9. Mitsumori, M.; Enishi, O.; Shinkai, T.; Higuchi, K.; Kobayashi, Y.; Takenaka, A.; Nagashima, K.; Mochizuki, M.; Kobayashi, Y. Effect of cashew nut shell liquid on metabolic hydrogen flow on bovine rumen fermentation. Anim. Sci. J. 2014, 85, 227-232. [CrossRef] [PubMed]

10. Pirondini, M.; Colombini, S.; Malagutti, L.; Rapetti, L.; Galassi, G.; Zanchi, R.; Crovetto, G.M. Effects of a selection of additives on in vitro ruminal methanogenesis and in situ and in vivo NDF digestibility. Anim. Sci. J. 2015, 86, 59-68. [CrossRef] [PubMed]

11. Hess, H.D.; Kreuzer, M.; Diaz, T.E.; Lascano, C.E.; Carulla, J.E.; Soliva, C.R.; Machmüller, A. Saponin rich tropical fruits affect fermentation and methanogenesis in faunated and defaunated rumen fluid. Anim. Feed Sci. Technol. 2003, 109, 79-94. [CrossRef]

12. Hess, H.D.; Beuret, R.A.; Loetscher, M.; Hindrichsen, I.K.; Machmüller, A.; Carulla, J.E.; Lascano, C.E.; Kreuzer, M. Ruminal fermentation, methanogenesis and nitrogen utilization of sheep receiving tropical grass hay-concentrate diets offered with Sapindus saponaria fruits and Cratylia argentea foliage. Anim. Sci. 2004, 79, 177-189. [CrossRef]

13. Calsamiglia, S.; Busquet, M.; Cardozo, P.W.; Castillejos, L.; Ferret, A. Essential oils as modifiers of rumen microbial fermentation. J. Dairy Sci. 2007, 90, 2580-2595. [CrossRef] [PubMed]

14. Jayanegara, A.; Leiber, F.; Kreuzer, M. Meta-analysis of the relationship between dietary tannin level and methane formation in ruminants from in vivo and in vitro experiments. J. Anim. Physiol. Anim. Nutr. 2012, 96, 365-375. [CrossRef] [PubMed]

15. Jayanegara, A.; Wina, E.; Takahashi, J. Meta-analysis on methane mitigating properties of saponin-rich sources in the rumen in vitro: Influence of addition levels and plant sources. Asian Australas. J. Anim. Sci. 2014, 27, 1426-1435. [CrossRef] [PubMed]

16. Jayanegara, A.; Goel, G.; Makkar, H.P.S.; Becker, K. Divergence between purified hydrolysable and condensed tannin effects on methane emission, rumen fermentation and microbial population in vitro. Anim. Feed Sci. Technol. 2015, 209, 60-68. [CrossRef]

17. Cieslak, A.; Zmora, P.; Stochmal, A.; Pecio, L.; Oleszek, W.; Pers-Kamczyc, E.; Szczechowiak, J.; Nowak, A.; Szumacher-Strabel, M. Rumen antimethanogenic effect of Saponaria officinalis L. phytochemicals in vitro. J. Agric. Sci. 2014, 152, 981-993. [CrossRef]

18. Śliwiński, B.J.; Soliva, C.R.; Machmüller, A.; Kreuzer, M. Efficacy of plant extracts rich in secondary constituents to modify rumen fermentation. Anim. Feed Sci. Technol. 2002, 101, 101-114. [CrossRef]

19. Sinz, S.; Marquardt, S.; Soliva, C.R.; Braun, U.; Liesegang, A.; Kreuzer, M. Phenolic plant extracts are additive in their effects against in vitro ruminal methane and ammonia formation. Asian-Australas. J. Anim. Sci. 2019, 32, 966-976. [CrossRef]

20. Liu, Y.; Ma, T.; Chen, D.; Zhang, N.; Si, B.; Deng, K.; Tu, Y.; Diao, Q. Effects of tea saponin supplementation on nutrient digestibility, methanogenesis, and ruminal microbial flora in Dorper crossbred ewe. Animals 2019, 9, 29. [CrossRef]

21. Makkar, H.P.S.; Blummel, M.; Becker, K. In vitro effects of and interactions between tannins and saponins and fate of tannins in the rumen. J. Sci. Food Agric. 1995, 69, 481-493. [CrossRef]

22. Wina, E.; Muetzel, S.; Hoffmann, E.; Makkar, H.P.S.; Becker, K. Saponins containing methanol extract of Sapindus rarak affect microbial fermentation, microbial activity and microbial community structure in vitro. Anim. Feed Sci. Technol. 2005, 121, 159-174. [CrossRef]

23. Jayanegara, A.; Marquardt, S.; Wina, E.; Kreuzer, M.; Leiber, F. In vitro indications for favourable non-additive effects on ruminal methane mitigation between high-phenolic and high-quality forages. Br. J. Nutr. 2013, 109, 615-622. [CrossRef]

24. Makkar, H.P.S. Quantification of Tannins in Tree and Shrub Foliage: A Laboratory Manual; Kluwer Academic Publishers: Dordrecht, The Netherlands, 2003. 
25. Hiai, S.; Nakajima, T. Color reaction of some sapogenins and saponins with vanillin and sulfuric acid. Planta Med. 1976, 29, 116-122. [CrossRef] [PubMed]

26. Theodorou, M.K.; Williams, B.A.; Dhanoa, M.S.; McAllan, A.B.; France, J. A simple gas production method using a pressure transducer to determine the fermentation kinetics of ruminant feeds. Anim. Feed Sci. Technol. 1994, 48, 185-197. [CrossRef]

27. Yanez-Ruiz, D.R.; Bannink, A.; Dijkstra, J.; Kebreab, E.; Morgavi, D.P.; O’Kiely, P.; Reynolds, C.K.; Schwarm, A.; Shingfield, K.J.; Yu, Z.; et al. Design, implementation and interpretation of in vitro batch culture experiments to assess enteric methane mitigation in ruminants-A review. Anim. Feed Sci. Technol. 2016, 216, 1-18. [CrossRef]

28. Menke, K.H.; Raab, L.; Salewski, A.; Steingass, H.; Fritz, D.; Schneider, W. The estimation of the digestibility and metabolizable energy content of ruminant feedingstuffs from the gas production when they are incubated with rumen liquor in vitro. J. Agric. Sci. Camb. 1979, 93, 217-222. [CrossRef]

29. Federation of Animal Science Societies. Guidelines for the Care and Use of Agricultural Animals in Research and Teaching, 3rd ed.; Federation of Animal Science Societies: Savoy, IL, USA, 2010; Available online: https://aaalac.org/about/Ag_Guide_3rd_ed.pdf (accessed on 2 June 2019).

30. AOAC. Official Methods of Analysis, 18th ed.; AOAC International: Arlington, VA, USA, 2005.

31. Van Soest, P.J.; Robertson, J.B.; Lewis, B.A. Methods for dietary fiber, neutral detergent fiber, and nonstarch polysaccharides in relation to animal nutrition. J. Dairy Sci. 1991, 74, 3583-3597. [CrossRef]

32. Fievez, V.; Babayemi, O.J.; Demeyer, D. Estimation of direct and indirect gas production in syringes: A tool to estimate short chain fatty acid production that requires minimal laboratory facilities. Anim. Feed Sci. Technol. 2005, 123-124, 197-210. [CrossRef]

33. Nocek, J.E.; Hart, S.P.; Polan, C.E. Rumen ammonia concentration as influenced by storage time, freezing and thawing, acid preservative, and method of ammonia determination. J. Dairy Sci. 1987, 70, 601-607. [CrossRef]

34. Iqbal, S.; Younas, U.; Chan, K.W.; Zia-ul-haq, M.; Ismail, M. Chemical composition of Artemisia annua L. leaves and antioxidant potential of extracts as a function of extraction solvents. Molecules 2012, 17, 6020-6032. [CrossRef]

35. Mueller-Harvey, I. Unravelling the conundrum of tannins in animal nutrition and health. J. Sci. Food Agric. 2006, 86, 2010-2037. [CrossRef]

36. Makkar, H.P.S.; Siddhuraju, P.; Becker, K. Plant Secondary Metabolites; Humana Press: Totowa, NJ, USA, 2007.

37. Anele, U.Y.; Refat, B.; Swift, M.L.; Zhao, Y.L.; Doublier, C.; McAllister, T.A.; Yang, W.Z. In vitro ruminal fermentation of ground and dry-rolled barley grain differing in starch content. Anim. Feed Sci. Technol. 2015, 203, 88-94. [CrossRef]

38. Lovett, D.; Lovell, S.; Stack, L.; Callan, J.; Finlay, M.; Conolly, J.; O’Mara, F.P. Effect of forage/concentrate ratio and dietary coconut oil level on methane output and performance of finishing beef heifers. Livest. Prod. Sci. 2003, 84, 135-146. [CrossRef]

39. Grandl, F.; Zeitz, J.O.; Clauss, M.; Furger, M.; Kreuzer, M.; Schwarm, A. Evidence for increasing digestive and metabolic efficiency of energy utilization with age of dairy cattle as determined in two feeding regimes. Animal 2018, 12, 515-527. [CrossRef] [PubMed]

40. Olijhoek, D.W.; Løvendahl, P.; Lassen, J.; Hellwing, A.L.F.; Höglund, J.K.; Weisbjerg, M.R.; Noel, S.J.; McLean, F.; Højberg, O.; Lund, P. Methane production, rumen fermentation, and diet digestibility of Holstein and Jersey dairy cows being divergent in residual feed intake and fed at 2 forage-to-concentrate ratios. J. Dairy Sci. 2018, 101, 9926-9940. [CrossRef]

41. Machmüller, A.; Soliva, C.R.; Kreuzer, M. Methane-suppressing effect of myristic acid in sheep as affected by dietary calcium and forage proportion. Br. J. Nutr. 2003, 90, 529-540. [CrossRef]

42. McSweeney, C.S.; Palmer, B.; McNeill, D.M.; Krause, D.O. Microbial interactions with tannins: Nutritional consequences for ruminants. Anim. Feed Sci. Technol. 2001, 91, 83-93. [CrossRef]

43. Goel, G.; Makkar, H.P.S.; Becker, K. Changes in microbial community structure, methanogenesis and rumen fermentation in response to saponin-rich fractions from different plant materials. J. Appl. Microbiol. 2008, 105, 770-777. [CrossRef]

44. Narvaez, N.; Wang, Y.; McAllister, T. Effects of extracts of Humulus lupulus (hops) and Yucca schidigera applied alone or in combination with monensin on rumen fermentation and microbial populations in vitro. J. Sci. Food Agric. 2013, 93, 2517-2522. [CrossRef] 
45. Guo, Y.Q.; Liu, J.X.; Lu, Y.; Zhu, W.Y.; Denman, S.E.; McSweeney, C.S. Effect of tea saponin on methanogenesis, microbial community structure and expression of mcrA gene, in cultures of rumen micro-organisms. Lett. Appl. Microbiol. 2008, 47, 421-426. [CrossRef]

46. Wallace, R.J.; Arthaud, L.; Newbold, C.J. Influence of Yucca schidigera extract on ruminal ammonia concentrations and ruminal microorganisms. Appl. Environ. Microbiol. 1994, 60, 1762-1767. [CrossRef] [PubMed]

47. Wang, Y.; McAllister, T.A.; Yanke, L.J.; Cheeke, P.R. Effect of steroidal saponin from Yucca schidigera extract on ruminal microbes. J. Appl. Microbiol. 2000, 88, 887-896. [CrossRef] [PubMed]

(C) 2020 by the authors. Licensee MDPI, Basel, Switzerland. This article is an open access article distributed under the terms and conditions of the Creative Commons Attribution (CC BY) license (http://creativecommons.org/licenses/by/4.0/). 